\title{
À flor da pedra. Formas tumulares e processos sociais nos cemitérios brasileiros*
}

\section{Oscar Calavia Sáez ${ }^{* * *}$}

Gosto também dos cemitérios porque são cidades monstruosas, enormemente povoadas. Pensem em quantos mortos não cabem nesse reduzido espaço, em todas as gerações de parisienses alocados ali para sempre, trogloditas estabelecidos definitivamente, encerrados nos seus pequenos panteões, nos seus pequenos buracos cobertos com uma laje ou assinalados com uma cruz, enquanto os vivos ocupam tanto espaço e fazem tanto ruído, os imbecis (Maupassant, 1891).

Guy de Maupassant refletia assim num relato de 1891, Les tombales, de tema entre o erótico e o humorístico, antes de dedicar mais dois longos parágrafos à arte que podia se encontrar nos cemitérios de Paris, "tão interessantes quanto os museus". A ideia lhe interessava. Num relato anterior - La morte, de 1887 - já tinha expressado, quase com as mesmas palavras, essa densidade, ao mesmo tempo demográfica e semântica, dos cemitérios, que não oferecia dúvidas na sua época, cem anos antes que uma nova moda sepulcral, a dos cemitérios-gramados, os tornasse menos loquazes, embora não menos significativos.

\footnotetext{
* Resenha de MotTA, Antônio. À flor da pedra. Formas tumulares e processos sociais nos cemitérios brasileiros. Recife, Fundação Joaquim Nabuco, 2009. Recebida para publicação em 05 de julho de 2011, aceita em 04 de setembro de 2011.

${ }^{\star *}$ Programa de Pós-Graduação em Antropologia Social. Universidade Federal de Santa Catarina. occs@uol.com.br
}

cadernos pagu (37), julho-dezembro de 2011:427-431. 
No entanto - falo por experiência própria -, pesquisar um cemitério costuma ser visto como uma ideia pitoresca ou extravagante, muito mais do que pesquisar um mercado ou um boteco, mesmo que seja precisamente no cemitério onde as declarações e as reticências sejam mais expressivas. É isso que confere valor ao livro de Antonio Motta, ao mesmo tempo em que define as suas fraquezas.

À flor da Pedra é um livro primorosamente editado e agradavelmente escrito, que pinça na literatura e na arte ocidentais - com referências em nota a outras tradições panoramas da relação entre o sujeito, a morte, a memória e os modos de dar sustento a ela nesses conjuntos monumentais que são os cemitérios. Detém-se especialmente na criação dos cemitérios como espaços de memória independentes da Igreja, aptos para dar cabida ao privatismo decimonónico; mostra como se desenvolveu neles o jazigo familiar, que dava eternidade à família burguesa, e como, mais tarde, esse doce lar tumular deixou passo a uma sepultura mais personalista, centrada nos casais ou nos indivíduos. Relata como as façanhas do trabalho, do comércio $e$ da filantropia encontraram seu espaço de glória nas comemorações estatuárias, e tudo isso tratando dos cemitérios brasileiros, embora com referências constantes a outras necrópoles famosas, especialmente francesas $e$ italianas. O livro oferece um interessante catálogo (que nunca poderia ser exaustivo) de sepulcros brasileiros especialmente expressivos, recolhendo a tradição de um velho estudo de Clarival do Prado Valadares, que atendia a esse setor habitualmente esquecido da arte nacional, $e$ também desencava alguns interessantes debates públicos sobre as polêmicas higienistas, a democratização do direito a uma sepultura pessoal e as mutáveis condições de classe dos cemitérios.

Tudo isso outorga interesse a esse livro, que, no mínimo, esclarece que para saber algo sobre o Brasil - ou sobre qualquer outro lugar - não se deveria deixar de consultar os seus mortos.

A fraqueza do livro se encontra também muito perto desse mérito. Afinal, os cemitérios falam muito, de modo que para não 
se perder na sua conversa, sempre um tanto convencional, seria conveniente centrar-se em algum dos seus ditos, ou buscar um outro lado do discurso. Sem dúvida os cemitérios falam, como diz o livro, do indivíduo, dando uma das melhores expressões possíveis a uma cosmologia individualista que no século XIX foi substituindo à da Igreja - ou que, para ser exato, foi se impondo à mesma Igreja. Mas vale a pena lembrar que toda essa exaltação decimonónica do morto individual pouco mais fez do que estendê-la à camada superior do Terceiro Estado, já que o monumento funeral consagrado à gloria mundana do defunto já ocupava antes os interiores dos templos, em benefício da nobreza $e$ do alto clero. O enterramento em terrenos exclusivamente dedicados a esse fim foi, sim, um feito da secularização e de um primeiro higienismo, mas de outra parte apenas restabeleceu uma tradição clássica que o cristianismo - uma das raras religiões que chegaram a aglutinar templo e sepultura - tinha interrompido. Não é nenhuma surpresa que a exaltação burguesa da família, com sua ênfase patriarcal, tenha um palco no cemitério, nem que a nuclearização dos lares e o encolhimento consequente das residências dos vivos tenham se manifestado igualmente nas últimas moradias. Afinal, o cemitério faz muito por se parecer à cidade: é desenhado de acordo com as mesmas ideologias e as mesmas teorias urbanísticas. Com a diferença de que os mortos ocupam menos espaço e são muito menos irrequietos que os vivos, e assim se sujeitam melhor ao planejamento. São dispostos, quase sem resistência, de acordo com o modelo. Justo por isso, descobrir no cemitério os modelos sociais em vigor tem algo de tautologia. E, pela mesma razão, o mais interessante que pode se encontrar nos cemitérios é aquilo que aparentemente se desvia do modelo. À flor da pedra trata dessas divergências em alguns momentos, por exemplo, quando trata do erotismo: seja qual for o grau da repressão ou da tolerância de uma sociedade, um cemitério é um dos últimos lugares em que se esperam manifestações desse tipo. E, contra essa expectativa, elas não são raras. Dois exemplos encontrados no cemitério de S. João Batista, 
no Rio de Janeiro, servem ao autor para sugeri-lo. Em ambos trata-se de uma relação entre esposos; mas há também essas imagens de mulher fatal, ou anjo feminino, ou belle dame sans merci, que proliferam nos cemitérios, sobre as quais não se diz nada para além de constatar sua presença intrigante. Elas tinham passagem franca na literatura da época; mas como chegaram a ser incluídas com tanta frequência num contexto habitualmente mais devoto como o dos cemitérios? Decerto, haveria outras variedades desse erotismo: efebos ou crianças apenas púberes, de mármore ou bronze, saltitando sobre os túmulos sem mais roupas que as da alegoria. Bastaria lembrar as estátuas jacentes dos Valois nos túmulos de Saint-Denis para lembrar que a contaminação mútua de erotismo e morte vem de longe, e que, curiosamente, só os cemitérios preservam algo dessa relação que o Ocidente erradicou de todo o resto dos fastos funerais.

Ou será que o erotismo surge como uma última manifestação de rebeldia? Falta no livro - se é que não falta nos cemitérios brasileiros - essa dimensão do túmulo como manifestação de heterodoxia, tão frequente pelo mundo afora.

Merece destaque no livro um detalhe a respeito da representação plástica do luto. Uma digressão prévia: é curioso observar como os estudos antropológicos sobre rituais funerais, sabendo que sua competência se exerce principalmente sobre as expressões formais de dor, assumem que haverá sempre uma outra dor, dimensão pungente e íntima, que o frio idioma da ciência não conseguirá expressar. E, no entanto, olhando com cuidado para algum desses mesmos monumentos do luto retratados em À flor da pedra, é difícil não pensar no íntimo alívio, para dizer pouco, que muitos terão experimentado ao encerrar suas relações sob pesadas inscrições de desolação; não são só as expressões obrigatórias dos sentimentos que variam, os sentimentos em si pouco têm de previsível, e é interessante observar o critério de seleção que a eles se aplica nos cemitérios. No livro ilustra-se uma exceção: a imagem de bronze de um homem com seu filho olhando melancolicamente um pão sobre 
uma mesa, junto à qual se vê uma cadeira vazia. Esse caso raro faz destacar por contraste uma distribuição de gênero muito diferente: são quase sem exceção estátuas femininas as que se ocupam de chorar permanentemente nos túmulos. Retratos de esposas ou filhas, ou mulheres genéricas (ou alegorias femininas da Humanidade ou a Pátria), choram no túmulo do esposo, do pai ou do Grande Homem. Quando uma mulher é a protagonista da sepultura, são crianças as que se ocupam de chorá-la. Mulher chora sempre, homem nunca, mesmo quando nada garante que ele tenha morrido antes - muitas vezes os túmulos eram encomendados com muita antecedência. Curiosamente, como o livro indica, acontece o contrário num daqueles expoentes do erotismo funeral, em que o homem nu que se inclina sobre uma mulher jacente comemora, ao que parece, um esposo que faleceu antes que a sua viúva, quem ideou o conjunto.

Definitivamente, o silêncio do túmulo é só aparente: na verdade ele fala tanto que diz o que quer e até o que não quer. $\grave{A}$ flor da pedra recolhe muito do primeiro; do segundo, um pouco menos do que caberia esperar. 